\title{
Live table fish transportation - a means of innovative value addition in the fish retail markets of Ludhiana, Punjab
}

\author{
A. U. MUZADDADI, T. AHMAD, MONIKA AND S. K. NANDA \\ ICAR-Central Institute of Post Harvest Engineering and Technology, Ludhiana - 141 004, Punjab, India \\ e-mail:drarmaan@gmail.com
}

\begin{abstract}
In the present study, different means of transportation of live table fish in Sherpur Fish Market, Ludhiana District in Punjab were investigated. Two methods, one for short distance (travel time $<2 \mathrm{~h}$ ) and the other for long distance transportation (travel time 2-6 h), were studied. The transportation method for short distance was with tricycle-rickshaw either pulled by humans or by a moped, wherein, a wooden cuboid $(1.5 \times 1.0 \times 1.0 \mathrm{~m})$ with internal polythene lining was used with a carrying capacity of 50-100 kg fish. In the long distance transportation method, polythene lined truck-pool of $3.1 \times 1.83 \times 0.75 \mathrm{~m}$ was used and about $600-700 \mathrm{~kg}$ fish per truck-pool was transported. About 50 to $100 \%$ fish mortality was observed in the long-distancecarriage or truck-pool method, whereas, only 10-20\% mortality was recorded in short-distance-carriage or cart method. The fish transported were primarily carps weighing 300-1500 g each and comprised catla (catla catla), rohu (Labeo rohita), mrigal (Cirrhinus mrigala), common carp (Cyprinus carpio), big-head carp (Hypophthalmichthys nobilis) and silver carp (Hypophthalmichthys molitrix). The live fish packaging and transportation were used as a means of value addition to ensure fresh quality and added market price per unit fish. The retail price of live table carps ranged from ₹ $120-200 \mathrm{~kg}^{-1}$ based on species of fish and its size, whereas, the dead and iced fish was priced below ₹ $100 \mathrm{~kg}^{-1}$. The major problems faced in live fish transportation were lack of aeration of water during transportation, inconvenient and cumbersome nature of existing method and accident proneness. The study suggested the need for scientific intervention in mainly two aspects such as: 1) to develop a handy method of live table fish transportation compatible to truck-pools and 2) to develop an aerator appropriate for the live-fish transportation containers in order to overcome the existing problems.
\end{abstract}

Keywords: Carps, Carrier, Live fish transportation, Table fish

Fish is transported for several purposes in live condition such as for breeding, rearing and grow-out since, in many cases, the grow-out sites (cages, ponds, lakes and rivers) are normally located at a distance from the nursery location that supplies juvenile fish (Stieglitz et al., 2012). However, in recent past, lot of emphasis has been given to live transportation of fish for human consumption as well (Erikson et al., 2006). Fish retains fresh quality when it is alive. Hence, consumers in India, particularly in North, East and North-east India, prefer live freshwater fish for consumption. Fish producers and vendors sell their fish in live condition by applying their own traditional techniques in North-east India, like use of bamboo barrels with polythene lining and mechanical agitation (Muzaddadi, 2011). In addition, live fish transportation to the laboratories has always been a difficult task for scientific studies (Gopalkrishnan, 2000). A wide range of techniques are being employed for fish seed (spawn, fry and fingerlings) transportation in India (Das et al., 2015). Two methods of fish seed transportation are in use viz., open system of seed transport that is used for short distance transport and closed system with oxygen packaging in polyethylene bags which is normally adopted for long distance transport (Jhingran and Pullin, 1985). However, transportation of larger fish frequently leads to large-scale mortality due to stress arising out of handling, packing, crowding and physical injury (Kutty, 1987; Singh et al., 2004; Basavaraja, 2007). Many researchers described methods for reducing such stress in order to reduce mortality of fish. Pre-conditioning at high density prior to packaging (Kumar, 1992), oxygen packaging (Jhingran and Pullin, 1985; Milwain et al., 2002), use of tranquilisers or anesthetics to reduce metabolic activity and transportation stress (Woynarovich and Horvath, 1980; Mishra et al., 1983; Mohamed and Devraj, 1997; Hasan and Bart, 2007) are some of the strategies for transporting fish in live condition. This present study invstigated two methods for transportation of table-size fish i.e., for short distance as well as for long distance.

The study was planned and carried out in two parts in Sherpur Fish Market, Ludhiana District in Punjab. Firstly to study the present status of live fish transportation in Sherpur Fish Market, Ludhiana Districts, a survey was conducted using PRA (Participatory Rural Appraisal) and also by using a questionnaire. The second part of the study involved analysing water quality, fish density, fish load and survivability during transportation. In the first part of 
the study, information related to total amount of live fish transported, varieties of fish transported in live condition, price of the live fish as well as dead fish, percentage of fish mortality, mode of aeration as well as use of chemicals as anesthetics were documented through PRA technique and questionnaire.

In the $2^{\text {nd }}$ part, water quality parameters such as temperature (using digital thermometer), $\mathrm{pH}$ (using $\mathrm{pH}$ meter and $\mathrm{pH}$ paper), ammonia and $\mathrm{CO}_{2}$ (Prakash and Aglave, 1997) and dissolved oxygen (Winkler's method modified by Strickland and Parson, 1972) were recorded in the containers after transportation. In addition, hardness and total dissolved solids were also recorded. The fish density was calculated as number of fish per litre or per container. Total plate count (TPC) and total coliform count were also estimated as per APHA (2005) methods. In addition, survivability was calculated using the following formula:

$$
\mathrm{S}(\%)=\frac{\mathrm{LF}}{\mathrm{ILF}} \times 100
$$

where, $\mathrm{S}=$ Survivability, $\mathrm{LF}=$ Number live fish in the container, ILF = Initial number of live fish in the container

Samples were collected from the surface and bottom layers from the water column separately. Statistical analysis was done by performing one way ANOVA (Post Hoc, Duncan) and student's t-test to compare the means using SPSS 15.0 (2005) at 5\% confidence level.

Two major traditional methods of live fish transportation and storage were recorded in Ludhiana, Punjab which included:

1. Truck-pool method: The whole backside of truck is converted into a small pool of water with plastic (LDPE sheets) linings to hold water. Aeration was provided manually. This is used for long distance (travel time 2-6 h) transport.

2. Motorcycle cart method: A tri-cycle cart was made with a back-loader which is pulled by a motorcycle. The backloader was lined with LDPE and converted to a small pool of water wherein fish were kept. This is used for short distance transportation.
Detailed information about these 2 methods of transportation of live fish are summarised in Table 1. The truck-pool method was largely used for transporting live table fish from farmers' pond to the market for wholesale purpose. Frequently used trucks were the mini trucks with backside dimensions $3.1 \times 1.83 \times 0.75 \mathrm{~m}$ (length $\mathrm{x}$ width $\mathrm{x}$ water depth) carrying 500-1000 kg fish per trip. These fish, mainly the live carps (Table 2) fetched higher prices than their dead or iced counterparts. The price of live fish was observed to be about $50 \%$ more than that of dead fish during the study period. The trucks with live fish travelled more than $100 \mathrm{~km}$ to reach Ludhiana market during night hours and also in early morning hours, with no water renewal and temperature control on the way. Manual aeration was done by shaking the aluminum hundi (container). or a flattened tube of motor vehicle tyre kept on the surface of water which was continuously agitated by a worker sitting on the brim. This task was difficult especially during freezing winter season and hence the wages rise high as ₹500/- per trip per labourer and about 4 persons were needed per trip for complete aeration. The fish traders reported that truck-pool transportation of fish had been unsafe for the workers due to high risks of accidents. Moreover the ultimate survivability

Table 1. General information of traditional live fish carrier systems

\begin{tabular}{lll}
\hline & Truck-pool & Motorcycle cart \\
\hline $\begin{array}{l}\text { Dimensions (m) } \\
\text { Water depth (m) }\end{array}$ & $3.1 \times 1.83 \times 0.75$ & $1.5 \times 1.0 \times 0.50$ \\
Fish density (kg l' $\left.{ }^{-1}\right)$ & $0.2-0.5$ & $0.3-0.5$ \\
$\begin{array}{l}\text { Total fish load } \\
\text { (kg per container) }\end{array}$ & $500-1000$ & $0.2-5.0$ \\
$\begin{array}{l}\text { No. of persons engaged } \\
\text { for aeration }\end{array}$ & 4 & $50-100$ \\
$\begin{array}{l}\text { Distance travelled (km) } \\
\text { Duration of travel/ }\end{array}$ & $60-200$ & 2 \\
$\begin{array}{l}\text { storage (h) } \\
\text { Fish survival rate (\%) }\end{array}$ & $1-6$ & $10-50$ \\
$\begin{array}{l}\text { Starvation } \\
\text { Water exchange }\end{array}$ & $50-60$ & $<1$ \\
$\begin{array}{l}\text { Use of chemicals as } \\
\text { anesthetics }\end{array}$ & $\begin{array}{l}\text { Yes } \\
\text { Yes, but not }\end{array}$ & No-95 \\
\hline
\end{tabular}

Table 2. Length, weight and price of frequently transported live carps $(n=200)$

\begin{tabular}{|c|c|c|c|c|}
\hline Species & $\begin{array}{l}\text { Length }(\mathrm{cm}) \\
(\text { mean } \pm \text { SD) }\end{array}$ & $\begin{array}{l}\text { Weight }(\mathrm{kg}) \\
(\text { mean } \pm \mathrm{SD})\end{array}$ & $\begin{array}{l}\text { Live fish price } \\
\text { (₹) }\end{array}$ & $\begin{array}{l}\text { Dead fish price } \\
\text { (₹) }\end{array}$ \\
\hline Rohu (Labeo rohita) & $33.1 \pm 4.4$ & $0.36 \pm 0.15$ & $150-200$ & $80-100$ \\
\hline Catla (Catla catla) & $35.8 \pm 6.21$ & $0.72 \pm 0.39$ & $150-250$ & $80-120$ \\
\hline Murag (naini) / Mrigal (Cirrhinus mrigala) & $25 \pm 8.04$ & $0.40 \pm 0.34$ & $100-200$ & $80-100$ \\
\hline Common carp (Cyprinus carpio) & $38 \pm 11.5$ & $0.78 \pm 0.37$ & $120-180$ & $80-100$ \\
\hline Bighead carp (Hypophthalmichthys nobilis) & $40.5 \pm 3.08$ & $0.45 \pm 0.35$ & $100-200$ & $60-100$ \\
\hline Silver carp (Hypophthalmichthys molitrix) & $35.5 \pm 2.03$ & $0.32 \pm 0.20$ & $100-200$ & $60-100$ \\
\hline
\end{tabular}


of fish was only about $50-60 \%$ on arrival at the destination markets.

The motorcycle cart was constructed locally by attaching a loader on two wheels. The loader with a dimension of $1.5 \times 1.0 \times 0.50 \mathrm{~m}$ (length $\mathrm{x}$ width $\mathrm{x}$ water depth) was temporarily lined with LDPE sheet and could carry about 50-100 kg fish per trip for short distance $(10-50 \mathrm{~km})$. At least, 2 workers were engaged per trip for riding the motorcycle and aerating the water with hand. The short distance travel with less than $1 \mathrm{~h}$ journey time was destined for local retail fish markets and had about 70-95\% fish survivability.

Fish density in all these 2 systems was neither maintained scientifically nor kept by following any thumb rule. No consideration was given to the factor of space. In some truck-pool systems, the density was even $6 \mathrm{~kg} \mathrm{l}^{-1}$. However, the recommended densities are 1:1 and 1:1.5 (water to fish) for carp transportation and stocking, respectively (Berka, 1986). The fishers, out of ignorance, wanted to maximise the profit level by loading excess weight of fish in both the systems and thus, ending up with high fish mortality. They loaded about $1000 \mathrm{~kg}$ fish in truck-pool and $100 \mathrm{~kg}$ in carts per trip (Table 1).

The results of the analysis of water samples from the truck-pool and motorcycle cart are summarised in Table 3. It was observed that the DO level of the surface water was higher than that of bottom water. Motorcycle cart had very high level of DO in surface water which was as high as $9.66 \mathrm{mg} \mathrm{l}^{-1}$ and in contrast, the bottom water had poor levels of DO $(<1.5$ $\left.\mathrm{mg}^{-1}\right)$. Two reasons were apparent, first the vigorous surface agitation by hand with no vertical mixing of water columns increased DO in surface and secondly the fish remained mostly in the bottom layer due to disturbance on the surface and consumption of DO eventually increased resulting in low DO in the bottom layer of water. On the other hand, there was almost no utilisation of DO in surface layer because of the disturbances caused by the manual aeration. The most important single factor in transporting fish is providing an adequate level of dissolved oxygen. However, an abundance of oxygen within a tank does not necessarily indicate that the fish are in good condition (Berka, 1986). In marked contrast to the road transport of terrestrial livestock, live fish transport involves the requirement to provide a life support system and the most critical component is a means of providing oxygen to support their normal respiration (Wedemeyer, 1996a, b). Failure to do so rapidly results in hypoxia, followed by death. The crucial factors underlying oxygen consumption by fish in relation with oxygen metabolism during transportation are fish weight and water temperature, as bigger fish and those transported in warmer water need more oxygen (Piper et al., 1982).

Dissolved $\mathrm{CO}_{2}$ was in higher levels in bottom water layers in truck-pool and motorcycle cart. Highest $\mathrm{CO}_{2}$ was recorded in carts (228 $\left.\mathrm{mg} \mathrm{l}^{-1}\right)$ (Table 3 ). This can be attributed to the absence of vertical mixing of water columns and deposition of heavier polluted water in the bottom. The $\mathrm{pH}$ of the bottom water also was lower than that of surface water. With increasing transport time, $\mathrm{CO}_{2}$ production through fish respiration shifts water $\mathrm{pH}$ towards acidity (Piper et al., 1982). Water $\mathrm{pH}$ levels about 7-8 are considered as optimum.

Ammonia $\left(\mathrm{NH}_{3}\right)$ builds up in transport water due to protein metabolism of the fish and bacterial action on the waste. In the present cases, ammonia levels were found to be on the higher side in both the transportation systems, near $1.7 \mathrm{ppm}$ in truck-pool and $1.3 \mathrm{ppm}$ in carts. However, none of the systems had ammonia at 2 ppm level, which is highly toxic to even ammonia-tolerant fish like carps (Aravindakshan et al., 2011). Decreasing metabolic rate of the fish by lowering the water temperature and thus lessening fish activity, reduces the production of $\mathrm{NH}_{3}$ (Berka, 1986). Low $\mathrm{pH}$ and ammonia levels are reported to affect the ability of hemoglobin to combine with oxygen (Biswas, 1990). Importantly, the proportion of toxic ammonia and $\mathrm{CO}_{2}$ contents are direct functions of $\mathrm{pH}$ (Berka, 1986). The accumulation of free carbon dioxide in water lowers the $\mathrm{pH}$ and increases the degree of ionisation of the ammonia molecule that is toxic to fish.

Total solids and hardness recorded were higher in the cart method, however, the range was within acceptable limits (500 $\left.\mathrm{mg} \mathrm{l}^{-1}\right)$ (Jensen, 2015). Partial renewal of water

Table 3. Water quality parameters recorded from the trucks and motorcycle cart (Mean $\pm \mathrm{SE}$ )

\begin{tabular}{|c|c|c|c|c|}
\hline \multirow{2}{*}{ Parameters } & \multicolumn{2}{|c|}{ Truck-pool } & \multicolumn{2}{|c|}{ Motorcycle cart } \\
\hline & Surface & Bottom & Surface & Bottom \\
\hline Temperature $\left({ }^{\circ} \mathrm{C}\right)$ & $15.5 \pm 1.3$ & - & $18.6+1.2$ & - \\
\hline Dissolved oxygen $\left(\mathrm{mg} \mathrm{l}^{-1}\right)$ & $5.8 \pm 1.2$ & $3.33 \pm 1.5$ & $8.3 \pm 1.3$ & $2.1 \pm 0.5$ \\
\hline Carbon dioxide $\left(\mathrm{mg} \mathrm{l}^{-1}\right)$ & $94.0 \pm 5.5$ & $168.0 \pm 8.3$ & $128.5 \pm 5.3$ & $228.5 \pm 7.3$ \\
\hline Ammonia $\left(\mathrm{NH}_{3}\right)(\mathrm{ppm})$ & $1.6 \pm 0.3$ & $1.5 \pm 1.0$ & $1.1 \pm 0.2$ & $1.3 \pm 0.3$ \\
\hline $\mathrm{pH}$ & $7.2 \pm 0.3$ & $6.8 \pm 0.2$ & $6.7 \pm 0.3$ & $6.5 \pm 0.3$ \\
\hline Hardness ( $\left.\mathrm{mg} \mathrm{l}^{-1}\right)$ & $87.33 \pm 5.5$ & - & $106.0 \pm 3.3$ & - \\
\hline Total solids $\left(\mathrm{mg} \mathrm{l}^{-1}\right)$ & $0.79 \pm 0.3$ & - & $0.49 \pm 0.1$ & - \\
\hline
\end{tabular}


during transport may contribute to better fish survivability. Water temperature in truck-pool and carts was about 15 and $18^{\circ} \mathrm{C}$, respectively (Table 4 ). When water temperature is low, the $\mathrm{pH}$ remains higher and metabolism in fish physiological system decreases.

Fishers made the fish to starve for about 4-8 h prior to transportation in both the transportation systems. Many studies underline starvation of fish before transporting them for several benefits. The production of $\mathrm{NH}_{3}$ by bacterial action can be decreased by shipping fish only after food has been withheld long enough to void the stomach and intestine (Berka, 1986). The fish should be left to starve for at least a day; if the digestive tract of the fish is not totally cleaned, the possible time of transport is reduced to half, though the conditions may be the same (Pecha et al., 1983). (Table 4). TPC was highest in truck-pool with more than $7 \mathrm{cfu} \mathrm{m} \mathrm{ml}^{-1}$ of water and about $5 \mathrm{cfu} \mathrm{ml}^{-1}$ in cart. Faecal coliforms in truck-pool showed highest count of about $5 \log \mathrm{cfu} \mathrm{ml}{ }^{-1}$ and lesser counts in cart water (about $3.7 \log \mathrm{cfu} \mathrm{ml}^{-1}$ ). These counts are beyond the acceptable limits and are indicators of unhygienic practices, poor quality of water and poor handling practices followed.

Table 4. Water quality parameters recorded from the trucks and motorcycle cart in terms of temperature, total plate count (TPC) and faecal coliform count (means \pm SE)

\begin{tabular}{|c|c|c|}
\hline Parameters & Truck-pool & Motorcycle cart \\
\hline Temperature $\left({ }^{\circ} \mathrm{C}\right)$ & $15.5 \pm 1.3$ & $18.6+1.2$ \\
\hline TPC (log cfu ml-1) & $7.3 \pm 1.1$ & $4.4 \pm 1.0$ \\
\hline $\begin{array}{l}\text { Faecal coliform } \\
\left(\log \mathrm{cfu} \mathrm{m}^{-1}\right)\end{array}$ & $5.2 \pm 0.8$ & $3.7 \pm 1.0$ \\
\hline
\end{tabular}

Non-air breathing fish die out of water and spoil very fast and general preservation methods are employed to keep fish fresh. However, none of the preservation methods can retain the freshness of live fish even for a short period of time, because the preservation methods can only retard the process of spoilage but cannot stop the post-mortem physiological changes which are destined to occur in fish muscle. The customers treat live fish as a natural guarantee of freshness. Such fish also has least possibility of being treated with chemical preservatives. Live fish transportation is a means of value addition to fish, because a live table fish fetches almost double the price to that of its dead counterpart. The major problems of live fish transportation observed during the present study were lack of uniform aeration of water during transportation, poor water quality, inconvenient, cumbersome nature of existing methods and susceptibility to accidents The study suggested the need for scientific intervention in mainly two aspects such as: 1) to develop a handy method of live table fish transportation compatible to truck-pools and 2) to develop an aerator appropriate for the live-fish transportation containers in order to overcome the existing problems. Such system needs to be user friendly, low-cost, eco-friendly and easy to operate. Scientific interventions in live-fish transportation can help the fishers earn more profit and consumers gain quality fish.

\section{Acknowledgements}

The authors are highly grateful to ICAR-CIPHET, Ludhiana for providing support for the study. The authors are also thankful to the fishers of Sherpur Fish Market, Ludhiana, Punjab for providing information to make the study successful.

\section{References}

APHA 2005. Standard methods for the examination of water and waste water, $21^{\text {st }}$ edn. American Public Health Association, Washington, DC, USA.

Aravindakshan, P. K., Singh, S. K., Sarkar, B., Majhi, D., Jena, J. K., Pani, K. C., Muduli, H. K., Ayyappan, S., Mohapatra, B. C. and Sarangi, N. 2011. Oxygen consumption of carps during live transport. Indian J. Fish., 58(4): 67-70.

Basavaraja, N. 2007. Freshwater fish seed resources in India. In: Bondad-Reantaso, M. G. (Ed.), Assessment of freshwater fish seed resources for sustainable aquaculture. FAO Fisheries Technical Paper No. 501, FAO, Rome, Italy, p. 267-327.

Berka, R. 1986. The transport of live fish, A review. EIFAC Tech Paper, 48: 52 pp.

Biswas, K. P. 1990. A textbook of fish, fisheries and technologies, NPH Ltd., Delhi, 53 pp.

Das, P. C., Mishra, B., Pati, B. K. and Mishra, S. S. 2015. Critical water quality parameters affecting survival of Labeo rohita (Hamilton) fry during closed system transportation. Indian $J$. Fish., 62(2): 39-42.

Erikson, U., Hultmann, L. and Steen, J. E. 2006. Live chilling of Atlantic salmon (Salmo salar) combined with mild carbon dioxide anaesthesia I. Establishing a method for large-scale processing of farmed fish, Aquaculture, 252: 183-198.

Gopalakrishnan, A., Ponniah, A. G., Basheer, K. G., Padmakumar, Anuradha, K. and Lal, K. K. 2000. Successful transportation of wild stock of endangered "Thooli" (Labeo dussumieri) spawners without anaesthetics. Indian J. Fish., 47(3): 261-264.

Hasan, M. and Bart, A. N. 2007. Improved survival of rohu, Labeo rohita (Hamilton-Buchanan) and silver carp, Hypophthalmichthys molitrix (Valenciennes) fingerlings using low-dose quinaldine and benzocaine during transport. Aquac. Res., 38(1): 50-58.

Jensen, N. 2015. The importance of total dissolved solids in freshwater aquarium. http://www.plecoplanet.com/ forum/ showthread.php?t=3480 
Jhingran, V. G. and Pullin, R. S. V. 1985. A hatchery manual for the common Chinese and Indian major carps. ICLARM Studies and Reviews 11, Asian Development Bank, Manila, Philippines and International Center for Living Aquatic Resources Management, Manila, Philippines, 191 pp.

Kumar, D. 1992. Fish culture in undrainable ponds- A manual for extension, FAO Fisheries Technical Paper No. 325. FAO Fisheries and Aquaculture Department, Rome, Italy, 239 pp.

Kutty, M. N. 1987. Transport of fish seed and brood fish, In: Delince, G. A., Campbell, D., Janssen, J. A. I. and Kutty, M. N. (Eds.), Seed production-working paper for senior aquaculturist course at African Regional Aquaculture Centre, Port Harcourt, Nigeria, No. 13, 118 pp.

Milwain, G. K., Little, D. C., Kundu, N. and Immink, A. J. 2002. Overview of fish seed production and distribution in West Bengal, India. Institute of Aquaculture, University of Stirling and Institute of Wetland Management and Ecological Design Kolkata, India, Working Paper 7, 96 pp.

Mishra, B. K., Kumar, D. and Mishra, R. 1983. Observations on the use of carbonic acid anesthesia in fish fry transport. Aquaculture, 32(3-4): 405-408.

Mohamed, M. P. and Devaraj, M. 1997. Transportation of live finfishes and shellfishes. CMFRI Special Publication No. 66, Central Marine Fisheries Research Institute, Kochi, India, $43 \mathrm{pp}$.

Muzaddadi, A. U. 2011. A comparative study of live table fish transportation in Assam - using bamboo barrels and iron tanks. Fishing Chimes, 31(2): 45-48.

Pecha, O., Berka, R. and Kouril, J. 1983. Prepravapludku v polyetylénovychvacich (Fry transport in polyethylene bags) Ser. Metod. VURH Vodnany, (10): 16 pp.
Piper, R. G., McElwain, I. B., Orme, L. E., McCraren, J. P., Fowler, L. G. and Leonard, J. R. 1982. Fish hatchery management. U.S. Department of the Interior Fish and Wildlife Service, Washington, D.C., p. 348-71.

Prakash, C. and Aglave, N. K. 1997. Recent advances in management of water quality parameters in aquaculture, Central Institute of Fisheries Education, Mumbai, 50 pp.

Singh, R. K., Vartak, R. V., Balange, A. K. and Ghughuskar, M. M. 2004.Water quality management during transportation of fry of Indian major carps, Catla catla (Hamilton), Labeo rohita (Hamilton) and Cirrhinus mrigala (Hamilton). Aquaculture, 235(1-4): 297-302.

Stieglitz, J. D., Benetti, D. D. and Serafy, J. E. 2012. Optimising transport of live juvenile cobia (Rachycentron canadum): Effects of salinity and shipping biomass, Aquaculture, 364-365: 293-297.

Strickland, J. D. H. and Parsons, T. R. 1972. Determination of dissolved oxygen. In: A practical handbook of seawater analysis. Fisheries Research Board of Canada, Bulletin, 167: 71-75.

Wedemeyer, G. A. 1996a. Physiology of fish in intensive culture systems. Chapman and Hall, New York, 232 pp.

Wedemeyer, G. A. 1996b. Principles of salmonid cultures developments in aquaculture and fisheries science, Elsevier Amsterdam, p. 727-758.

Woynarovich, E. and Horvath, L. 1980. The artificial propagation of warm-water finfishes - A manual for extension. FAO Fisheries Technical Paper No. 201, 183 pp. 